\title{
Telaah Pemikiran KH. Abdurrahman Wahid Tentang Pondok Pesantren
}

\author{
M. Sufyan Riady, Moh. Wardi \\ Institut Dirosat islamiyah Al-Amien Prenduan Sumenep \\ msufyanriady@gmail.com, mohwardi@idia.ac.id
}

\begin{abstract}
Abstrak: Penelitian ini dilakukan dengan tujuan Untuk mengetahui konsep pendidikan Pondok Pesantren, bagaimana subkultur dan tata nilai, pola kepemimpinan dan kurikulum pondok pesantren menurut K.H. Abdurrahman Wahid. Adapun metode penelitian yang dipakai dalam penulisan skripsi ini adalah penelitian kualitatif artinya penelitian yang menggunakan data informasi berbagai macam teori yang diperoleh dari kepustakaan, baik itu diperoleh dari sumber data primer maupun data skunder. Berdasarkan deskripsi atas pemikiran $\mathrm{KH}$. Abdurrahman Wahid mengenai pendidikan Pondok Pesantren di atas, setelah penulis lakukan analisis lebih mendalam dapat ditarik kesimpulan bahwa Pendidikan Pondok Pesantren ialah pendidikan yang didasarkan pada keyakinan religius dan bertujuan untuk membimbing atau menghantarkan peserta didik menjadi manusia yang utuh dan mandiri. Ada tiga elemen yang mampu membentuk pondok pesantren sebagai sebuah subkultur, yaitu: (1) pola kepemimpinan pondok pesantren yang mandiri dan tidak terkoptasi oleh negara, 2) literatur-literatur kitab-kitab kuning sebagai rujukan umum yang selalu digunakan dari berbagai abad, dan 3) sistem nilai yang digunakan adalah bagian dari masyarakat luas. Pola Kepemimpinan Pondok Pesantren bersifat Khirarki dan Kurikulum di pondok pesantren ditujukan untuk "mencetak" ulama di kemudian hari.
\end{abstract}

\section{Kata Kunci: Pemikiran Abdurrahman Wahid, Pondok Pesantren}

Abstract: This research was conducted with the aim of knowing the concept of Islamic boarding school education, how subcultures and values, leadership patterns and Islamic boarding school curriculum according to K.H. Abdurrahman Wahid. The research method used in writing this thesis is qualitative research, meaning research that uses information data on various theories obtained from the literature, whether it is obtained from primary data sources or secondary data. Based on the description of the thoughts of $\mathrm{KH}$. Abdurrahman Wahid regarding Islamic Boarding School education above, after the author conducted a more in-depth analysis, it can be concluded that Islamic Boarding School Education is education based on religious 


\section{DIROSAT}

Journal of Islamic Studies

Volume 6, No 1 Januari-Juni 2021

ISSN: 2541-1667 (print); 2541-1675 (online)

beliefs and aims to guide or deliver students to become complete and independent human beings. There are three elements that are able to form Islamic boarding schools as a subculture, namely: (1) leadership patterns of Islamic boarding schools that are independent and not co-opted by the state, 2) yellow books literature as general references that are always used from various centuries, and 3. ) the value system used is part of the wider community. The pattern of Islamic boarding school leadership is hierarchical and the curriculum in Islamic boarding schools is intended to "print" ulama in the future.

Keywords : Thoughts KH. Abdurrahman Wahid, Islamic Boarding School

\section{Pendahuluan}

Seperti yang telah kita ketahui, pendidikan memang telah menjadi penopang dalam meningkatkan sumber daya manusia untuk pembangunan bangsa. Oleh karena itu, kita sebagai umat manusia tentunya sangat tidak ingin memiliki generasi yg tidak bisa meneruskan perjuangan seperti yang telah dilakukan tokoh-tokoh muslim terdahulu. Terbukti, bahwa suksesnya pendidikan di Indonesia khususnya pendidikan Islam adalah tidak lain sebagian besar peran dari mereka. Sebut saja Wali Songo, KH. Hasyim Asy'ari, KH. Ahmad dahlan, KH. Abdurrahman Wahid dan tokoh-tokoh lainnya. Yang mana mereka telah banyak mengukir sejarah pendidikan Islam yang begitu mengagumkan yang membuat dunia pendidikan Islam semakin maju dan berkembang.

Namun, seiring dengan perkembangan dan kemajuan dunia pendidikan saat ini, ternyata masih banyak yang perlu dibenahi ataupun diperbaiki. Penulis merasakan bahkan melihat masih banyak para pelajar yang melakukan hal-hal yang merugikan orang lain yang mana hal itu tidak sesuai dengan perkembangan dan kemajuan pendidikan saat ini. Sering kali kita melihat, mendengar ataupun membaca berita tentang pelajar yang terlibat dengan hal-hal negative seperti tawuran antar sekolah, kasus narkoba, putus sekolah, kebobrokan moral, ketertinggalan atas perkembangan ilmu pengetahuan, teknologi, dan peradaban. Selain itu, masukknya budaya barat dan penggunaan gadget serta social media secara berlebihan telah ikut mempengaruhi sikap para pelajar saat ini. Maka dengan kenyataan inilah, mengapa perkembangan dan kemajuan pendidikan saat ini sangat membutuhkan pembaharuan dari generasi ke generasi selanjutnya.

Ada beberapa faktor pendidikan Islam di Indonesia saat ini yang tetap terjaga. Salah satu Pendidikan Islam yang tetap terjaga saat ini Antara lain Pendidikan Islam yang terjadi di dalam Pondok pesantren. Pondok pesantren sangat berperan penting dalam mengembangkan pendidikan islam, bahkan jauh dari itu, pondok pesantren se akan-akan nyawa bagi umat islam.

Lebih lanjut mengenai pondok pesantren. Pondok pesantren adalah sebuah lembaga pendidikan Islam yang mana para santrinya mukim di asrama yang telah disediakan. Pondok Pesantren adalah sebuah kompleks dengan lokasi yang umumnya terpisah dari kehidupan di sekitarnya. ${ }^{1}$ Dalam kompleks itu berdiri

\footnotetext{
${ }^{1}$ Abdurahman Wahid, Meng Erakkan Tradisi, (Yogyakarta: Pt LKsi printing cemerlang, 2010), hlm. 6
} 


\section{DIROSAT}

Journal of Islamic Studies

Volume 6, No 1 Januari-Juni 2021

ISSN: 2541-1667 (print); 2541-1675 (online)

beberapa buah bangunan: rumah kediaman pengasuh (di daerah berbahasa jawa disebut kiai, di daerah berbahasa Sunda ajengan, dan di daerah berbahasa Madura nun dan bendara disingkat $r a$ ); sebuah surau atau masjid, tempat pengajaran diberikan (bahasa arab madrasah, yang juga lebih sering mengandung konotasi sekolah); dan asrama tempat tinggal para siswa pesantren (santri, pengambilalihan dari bahasa sanskerta dengan perubahan pengertian). ${ }^{2}$

Pondok pesantren, khususnya di Indonesia memiliki peran yang sangat besar, baik bagi kemajuan islam itu sendiri maupun bagi bangsa Indonesia secara keseluruhan. Selain itu, pesantren menurut Amien Haedari, adalah lembaga pendidikan yang berumur sangat tua, dan juga beliau mengatakan pesantren dikenal sebagai media pendidikan yang menampung seluruh jenis strata masyarakat. Baik dari kalangan darah biru, ningrat dan sejenisnya, maupun rakyat kecil yang miskin. ${ }^{3}$

Dalam buku yang sama, KH. Abdurrahman Wahid yang akrab dipanggil Gus Dur juga Berpendapat Bahwasannya pada fase-fase awal tersebut, system dan "kurikulum" pembelajaran yang dilakukan oleh pesantren pun tidak mengkhususkan pada masalah-masalah keagamaan dan lembaga pengkaderan ulama belaka. Lebih jauh pesantren pada waktu itu, sudah membuat pendidikan umum, yang di dalamnya tidak hanya mengajarkan agama saja. ${ }^{4}$

Sebagai sub-sistem dari system kemasyarakatan dan kebangsaan, pesantren menurut Gus Dur memiliki peranan yang cukup besar dalam mensosialisasikan dan merealisasikan program-program yang menjadi kebijakan pemerintah. Ambil contoh misalnya, pesantren berperan besar dalam mengupayakan pembudayaan nilai-nilai agama dalam kehidupan (ke) masyarakat (an), terutama dilingkungan pedesaan.

Mengapa peranan pesantren demikian menentukan? Sekali lagi, sejarah pula yang menjadikan atau membuatnya demikian. Pesantrenlah satu-satunya pranata dalam masyarakat dan memang sudah demikian watak aslinya - yang menjadi penghubung antar masyarakat dengan berdasarkan nilai-nilai agama. Karena itu, pesantren kerap dijuluki lembaga yang "anti struktur" tetapi populistis. Dan watak itu pula yang secara tercermin dalam gerak langkah Gus Dur, sehingga beliau bagaikan "kyai kelana"- penerus tradisi para wali atau para mubaligh penyebar Islam di Jawa - yang senantiasa membumikan nilai-nilai agama (ajaran pesantren) dalam masyarakat, sekaligus pembela kepentingan-kepentingan mereka dihapan pihak penguasa. ${ }^{5}$

Selain itu, Gus Dur menegaskan bahwa Pesantren bersifat dinamis, terbuka pada perubahan, dan mampu menjadi penggerak perubahan yang diinginkan. Bahkan lebih dari itu, Gus Dur juga memuat deskripsi dari kebudayaan Pesantren, yang disebut Gus Dur sebagai "Subkultur" tersendiri. Gus Dur Juga mempumpunyai "Tawaran Pembaharuan" yang dikemukakan Gus Dur untuk Pesantren, seperti

\footnotetext{
2 Ibid, hlm. 6

${ }^{3}$ Amin Haedari dkk, panorama pesantren dalam cakrawala modern, (Jakarta: Diva Pustaka, 2006) hlm. 11

${ }^{4}$ Ibid, hlm. 11

${ }^{5}$ Kh. Zainal Arifin Thoha, jagadnya Gus Dur, (Yogyakarta: kutub, 2010), hlm. 236
} 


\section{DIROSAT}

Journal of Islamic Studies

Volume 6, No 1 Januari-Juni 2021

ISSN: 2541-1667 (print); 2541-1675 (online)

dalam penyusunan kurikulum serta pembenahan manajemen kepemimpinan yang tetap merupakan agenda Pesantren hingga sekarang ini.

Tentu saja, kebanyakan khalayak sudah mafhum kalau Gus Dur berasal dari keluarga pesantren. Ia lahir, besar dan, berkembang di lingkungan pesantren. Gus Dur adalah orang yang "berangkat dari pesantren" dan (semestinya) kelak juga akan "kembali ke pesantren."

Kendati demikian, barangkali akan sedikit sekali orang yang mengetahui bagaimana pemikiran Gus Dur tentang pesantren. Dari sinilah peneliti merasakan adanya inspirasi untuk meneliti pemikiran KH. Abdurrahman Wahid tentang pendidikan pondok pesantren, yang mana masih relevan dengan realita pendidikan sekarang ini agar bisa dijadikan pedoman bagi para pelaksana pendidikan yang ada di lembaga pendidikan pondok pesantren pada khususnya dan masyarakat Indonesia pada umumnya.

\section{Metode Penelitian}

Penelitian ini menggunakan metode penelitian kajian kepustakaan (library research) yaitu meneliti dan menganalisa terhadap buku-buku dan karangan ilmiah yang dikemukakan oleh K.H. Abdurrahman Wahid (Gus Dus) yang berkaitan dengan penelitian sumber primer dalam penelitian ini adalah karya-karya yang ditulis oleh K.H. Abdurrahman Wahid (Gus Dur). Untuk melihat konsep pendidikan Pondok Pesantren menurut Gus Dur, maka peneliti melakukan survei kepustakaan tentang pemikiran Gus Dur. Dari hasil survei tersebut, maka peneliti memilih sumber primer yang digunakan dalam penelitian ini yakni buku yang berjudul Menggerakkan Tradisi, Prisma pemikiran Gus Dur. Sumber sekunder dalam penelitian ini adalah untuk menganalisis lebih mendalam konsep pendidikan Pondok Pesantren menurut K.H. Abdurrahman Wahid. Di antara buku-buku tersebut adalah jagadnya Gus Dur, Panorama Pesantren Dalam Cakrawala Modern, Tradisi Pesantren, Ensiklopedi Gus Dur, The Biografi Abdurrahman Wahid.

Metode ini merupakan usaha untuk menetapkan fakta dan mencapai kesimpulan mengenai hal-hal yang telah lalu. Secara sistematis dan obyektif, penulis mencari, mengevalusi dan menafsirkan bukti-bukti yang dapat dipakai untuk mempelajari masa lalu. Berdasarkan bukti yang dikumpulkan, penulis menarik kesimpulan mengenai masa lalu guna memperkaya penngetahuan penulis tentang bagaimana dan mengapa sesuatu kejadian dimasa lalu terjadi, serta proses bagaimana masa lalu itu menjadi masa kini. Hasil yang diharapkan adalah meningkatnya pemahaman tentang kejadian masa kini serta memperoleh dasar yang lebih rasional untuk melakukan pilihan-pilihan dimasa kini. ${ }^{6}$.

\section{Hasil Penelitian dan Penelitian}

Konsep dan gagasan K.H. Abdurrahman Wahid tentang pendidikan pondok pesantren secara jelas terlihat pada gagasannya tentang pembaruan pesantren. Menurutnya, semua aspek pendidikan pesantren, mulai dari visi, misi, tujuan,

${ }^{6}$ Lexy J. Moleong, Metodologi Penelitian Kualitatif (Bandung: PT Remaja Rosdakarya, 2009), hlm. 324 


\section{DIROSAT}

kurikulum, manajemen dan kepemimpinannya harus diperbaiki dan disesuaikan dengan perkembangan zaman era globalisasi. Meski demikian, menurut Gus Dur, pesantren juga harus mempertahankan identitas dirinya sebagai penjaga tradisi keilmuan klasik. Dalam arti tidak larut sepenuhnya dengan modernisasi, tetapi mengambil sesuatu yang dipandang manfaat-positif untuk perkembangan. ${ }^{7}$

Singkatnya, konsep pendidikan pondok pesantren ialah pendidikan yang didasarkan pada keyakinan religius dan bertujuan untuk membimbing atau menghantarkan peserta didik menjadi manusia yang utuh, mandiri dan bebas dari belenggu penindasan. ${ }^{8}$

Pesantren adalah sebuah kehidupan yang unik, sebagaimana dapat disimpulkan dari gambaran lahiriahnya: a. Komplek dengan lokasi yang umumnya terpisah dari kehidupan sekitar. Dalam lingkungan fisik seperti ini diciptakan semacam cara kehidupan yang memiliki sifat dan ciri tersendiri, mulai dari jadwal kegiatan yang menyimpang dari pengertian rutin kegiatan masyarakat disekitarnya yang mengikuti jadwal sholat rowatib, lamanya waktu belajar mengajar sampai masa belajar di pesantren itu sendiri. b. Struktur atau sistematika pengajaran yang diberikan. Dijumpai jenjang pelajaran yang berulang ulang dari tingkat ketingkat tanpa terlihat kesudahanya. c. Cara pemberian pelajaranya dan dalam penggunaan materi. Pengajian diberikan dalam bentuk seperti kuliah terbuka dimana sang kiai membaca, menerjemahkan dan kemudian menerangkan persolan-persolan yang disebutkan dalam teks, kemudian santri membaca ulang teks itu dihadapan kiai atau setelah kembali ke biliknya, ataupun dalam pengajian ulang antara sesama teman setingkat pengajianya. ${ }^{9}$ Dengan gambaran sepintas lalu tentang beberapa aspek pesantren yang memiliki keunikan sendiri tersebut telah memberikan gambaran konkrit tentang pengertian subkultur yang terdapat dalam kehidupan pesantren. Karena sesuatau itu dapat dikatakan sebagai subkultur minimal harus memiliki keunikanya sendiri dalam aspek-aspek berikut : cara hidup yang dianut, pandangan hidup dan tata nilai yang diikuti, serta hirarki kekuasaan intern tersendiri yang ditaati sepenuhnya. Dan ketiga persyaratan minimal itu terdapat dalam kehidupan di pesantren. ${ }^{10}$

Adapun ciri-ciri khas pondok pesantren yang sekaligus menunjukkan unsurunsur pokoknya, serta membedakanya dengan lembaga pendidikan lainya adalah : 1. Pondok. Yaitu tempat kiai dan santri tinggal. 2. Masjid. Dalam kontek ini masjid adalah pusat kegiatan ibadah dan belajar mengajar. 3. Santri. Yang terbagi dalam kelompok, yaitu santri mukim yang berasal dari jauh dan santri kalong yang berasal dari daerah sekitar pesantren dan biasanya mereka tidak menetap dipesantren. 4 . Kiai 5. Kitab-kitab islam klasik atau yang lebih dikenal dengan istilah kitab kuning, yang dikarang oleh ulama terdahulu, mengenai berbagai macam ilmu pengetahuan agama islam dan bahasa arab. ${ }^{11}$

\footnotetext{
${ }^{7}$ Faisol, Gus Dur \& Pendidikan Islam: Upaya Mengembalikan Esensi Pendidikan di Era Global (Jogjakarta: Ar-Ruzz Media, 2013),hlm. 26-27

${ }^{8}$ Ibid, hlm. 115

${ }_{9}^{9}$ Abdurrahman Wahid, Menggerakkan Tradisi, (LkiS, Yogyakarta, 2010. h. 3-7

10 Ibid, hlm. 9-10

11 Ibid, hlm.47-50
} 


\section{DIROSAT}

Journal of Islamic Studies

Volume 6, No 1 Januari-Juni 2021

ISSN: 2541-1667 (print); 2541-1675 (online)

Sistem pengajaran yang bermula dari sorogan dimana seorang kiai mengajar santrinya yang masih berjumlah sedikit secara bergilir santri persantri, pendidikan di pesantren kemudian berkembang menjadi sistem komplek. Pengajian sorogan ini diikuti oleh pengajian weton, dimana seorang kiai duduk dilantai masjid atau beranda rumahnya sendiri membacakan dan menerangkan teks-teks keagamaan dengan dikerumuni oleh santri-santri yang mendengarkan dan mencatat uraianya. ${ }^{12}$ Dari pengajaran sorogan dan weton ini kemudian muncullah sistem pendidikan yang lengkap, dimana secara kolektif pesantren menawarkan pengajaran dalam unit-unit yang terpisah satu dari yang lain dan berdiri sendiri. Seorang santri dapat memilih unit-unit mana saja yang diikutinya, biasanya setelah konsultasi dengan kiai dan gurunya sehingga tersusunlah kurikulum individual yang sangat fleksibel dan sesuai dengan kebutuhan pribadi seorang santri sendiri. Dalam menentukan kurikulum dan pelayanan individual kepada santri inilah muncul watak elitis dari pesantren, yaitu dalam pemberian prioritas kepada sejumlah santri yang diistimewakan. Dasar pembedaan pelayanan ini, dalam bentuk pemberian pelajaran tersendiri oleh kiai, adalah potensi kecerdasan yang tinggi atau hubungan sosial yang intensif antara orang tua santri dan kiai.

\section{Pesantren Sebagai Subkultur Dan Tata nilai}

Pesantren adalah sebuah kehidupan yang unik, sebagaimana dapat di simpulkan dari gambaran lahiriyahnya. Pesantren adalah kompleks dengan lokasi yang umumnya terpisah dari kehidupan di sekitarnya. Dalam kompleks itu berdiri beberapa buah bangunan; rumah kediaman pengasuh (di daerah berbahasa jawa di sebut kiai, di daerah berbahasa sunda ajengan, dan di daerah berbahasa madura nun atau bendara, di singkat $\mathrm{ra}$ ); sebuah surau atau masjid, tempat pengajaran di berikan (bahasa arab madrasah, yang juga lebih sering mengundang konotasi sekolah); dan asrama tempat tinggal para siswa pesantren ( santri, pengambilalihan dari bahasa sanskerta dengan perubahan pengertian). ${ }^{13}$ Tidak ada suatu pola tertentu yang diikuti dalam pembinaan fisik sebuah pesantren sehingga dapatlah dikatakan penambahan bangunan dalam lingkungannya seringkali mengambil bentuk improvisasi sekenanya belaka.

Pesantren memiliki pola pendidikan yang unik, kata Gus Dur, sehingga tepat disebut sebagai subkultur. Setidaknya ada tiga elemen dasar yang menguatkan posisi pesantren sebagai subkultur. Pertama, kepemimpinan kiai di pesantren lepas dari struktur pemerintahan desa. Selain itu, pola kepemimpinan kiai di pesantren juga menganut ciri-ciri pramodern yang berasakan kepercayaan, bukan pola patronklien yang semu.

Struktur pengajaran yang unik dan memiliki ciri khas tentu saja juga menghasilkan pandangan hidup dan aspirasi yang khas pula. Visi untuk mencapai penerimaan di sisi allah di hari kelak menempati kedudukan terpenting dalam tata nilai di pesantren, Visi mana dalam terninologi pesantren dikenal dengan nama keikhlasan (berbedan dengan keikhlasan yang dikenal di luar lingkungan masyarakat yang mengandung pengertian ketulusan dalam menerima, memberikan

12 Ibid, hhlm. 138-140

${ }^{13}$ Abdurrahman wahid, menggerakkan tradisi, (Yogyakarta: pt LKiS, 2010) hlm. 3-4 


\section{DIROSAT}

Journal of Islamic Studies

Volume 6, No 1 Januari-Juni 2021

ISSN: 2541-1667 (print); 2541-1675 (online)

dan melakukan sesuatu diantara sesama makhluk). Orientasi ke arah kehidupan alam akhirat ini (dikenal dengan terminologi pandangan hidup ukhrawi), yang terutama ditekankan pada perintah-perintah agama seteliti dan selengkap mungkin merupakan pokok dasar kehidupan pesantren, sebagaimana dapat ditemukan pada literatur yang diwajibkan di dalamnya.

Dengan gambaran sepintas lalu tetang beberpa aspek pesantren yang memiliki keunikannya sendiri bila dibandingkan dengan kehidupan di luarnya, telah dicoba untuk memberikan gambaran konkrit tentang pengertian subkultur yang terdalam kehidupan di pesantren. Sebagaimana sering terlihat uraian sosiologis, sebuah subkultur minimal harus memiliki keunikan sendiri dalam aspek-aspek berikut: cara hidup yang dianut, pandangan hidup dan tata nilai yang diikuti, hierarki kekuasaan intern tersendiri yang ditaati sepenuhnya ketika persyaratan minimal ini terdapat dalam kehidupan di pesantren sehingga dirasa cukup untuk mngenalkan predikat subkultur pada kehidupan itu. perbandingan terdekat yang paling aktual dewasa ini, pernah ditujukkan oleh kolumnis H. Mahbub djunaidi dalam sebuah tulisannya di majalah tempo, adalah dunia kaum hippies. Dengan life pattern, mores, and internal authority yang berbeda dengan masyarakat di luarnya, kaum hippies menciptakan sebuah subkultur dengan keunikannya tersendiri pula, bagaimana halnya dengan pesantren. ${ }^{14}$

Dengan pola kehidupan yang unik, pesantren mampu bertahan selama berabad-abad untuk mempergunakan nilai-nilai hidupnya. Oleh karena itu, dalam jangka panjang pesantren berada dalam kedudukan kultural yang relatif lebih kuat dari pada masyarakat di sekitarnya. Kedudukan ini dapat dilihat dari kemampuan pesantren untuk melakukan transformasi total dalam sikap hidup masyarakat sekitarnya, tampa iya sendiri harus mengorbankan identitas dirinya pola bertumbuh hampir setiap pesantren menunjukkan gejala kemampuan melakukan perubahan total. Bermula dari inti sebuah surau guna keperluan ibadah dan pengajaran, pesantren kemudian berkembang menjadi sebuah lembaga masyarakat yang memainkan peranan dominan dalam pembentukan tata nilai bersama yang berlaku bagi kedua belah pihak.

Dalam proses pembinaan inti surau yang kecil sehingga menjadi sebuah lembaga masyarakat yang kompleks dengan kelengkapannya sendiri, pesantren juga mengubah pola kehidupan masyarakat di sekitarnya. Sebuah kasus dapat ditunjukkan, yaitu sejarah perubahan pesantren tebu ireng di jombang masyarakat pedusunan tempat itu dapat memulainya adalah sebuah masyarakat serba keduniawian (mondaan) yang didukung oleh kehidupan yang relatif makmur dengan adanya sebuah pabrik gula di salah satu pedukuhan desa itu. Sikap hidup masyarakat jiwa lama, yang berorientasi pada harmoni dengan sang pencipta dalam suatu kehidupan yang serba ke agamaan, bersingggungan dengan ekses-ekses dari pihak kahidupan ekonomi liberal yang mengandung eksistensi pihak gula itu. proses akulturasi hasil perbenturan watak rawan: hilangnya rasa aman perorangan karena gangguan "jago-jago" dan meluasnya relativitas moral. Berdirinya sebuah pesantren di tempat itu, pada mulanya memperoses tantangan keras dari masyarakat namun

${ }^{14} \mathrm{Ibid}, \mathrm{hlm} 10$ 


\section{DIROSAT}

Journal of Islamic Studies

Volume 6, No 1 Januari-Juni 2021

ISSN: 2541-1667 (print); 2541-1675 (online)

lambat laun masyarakat itu mengalami transformasi menjadi sebuah pola kehidupan yang baru, di mana nilai kehidupan beragama kembali mendapatkan tempat yang dominan. Transformasi pola kehidupan masyarakat itu bersamaan dan menjadi sarana bagi perkembangan pesantren tebu ireng sendiri hingga akhirnya pesantren itu memiliki kedudukan kultural yang relatif lebih kuat dibangun dengan unsur lain dalam masyarakat. 15

Pola yang serupa walaupun dalam kilasan (scene) ukuran yang tepat berbeda juga terdapat dalam pertumbuhan pesantren lain. Kebudayaan pesantren pendidikan sebagai salah satu bentuk reaksi terhadap pola kehidupan tertentu yang dianggap rawan, dan dengan demikian berdirinyya pesantren itu sendiri juga menjadi salah satu bagian dari tranformasi kultural yang berjalan dalam jangka waktu sangat panjang. Karena sebagai titik mula proses tranformasi, dengan sendirinya pesantren dipaksa oleh keadaan menjadi alternatif terhadap pola kehidupan yang ada. Peranan sebagai pilihan ideal ini sangat sesuai dengan perwujudan kultural agama islam yang sampai ke kepulauan nusantara. Sebagai mana dapat disimpulkan dari sejarah penyebaran islam di kawasan ini, perwujudan kultural islam adalah perpaduan antara doktrin-doktrin formal islam dan kultus para wali (yang berpuncak pada kultus wali songo), sebagai sisa pengaruh pemujaan orang-orang suci (hermits) dalam agama Hindu. Perwujudan kultural ini tampak nyata sekali dalam asketisme (bahasa Arab: az-zuhd, sering kali dinamai pula "kealiman" di negeri ini) yang mewarnai kehidupan agama islam di kepulauan nusantara, tidak sebagai mana di negeri negeri arab sendiri sepanjang sejarahnya.

Asetisme yang digunakan pesantren sebagai proyeksi pilihan ideal bagi pola kehidupan yang dilanda krisis di masyarakat sekitarnya, akhirnya menimbulkan pesantren sebagai unit budaya yang berdiri terpisah dari dan pada waktu bersamaan menjadi bagian dari kehidupan masyarakat. Peranan berganda inilah yang sebenar-benarnya dapat dikatakan menjadi ciri utama pesantren sebagai sebuah subkultur. ${ }^{16}$ Dalam menjalankan peranan ganda ini, Pesantren terlibat dalam proses penciptaan tata nilai yang memiliki dua unsur utama, yaitu peniruan, adalah usaha yng dilakukan terus-menerus secara sadar untuk memindahkan pola kehidupan para sahabat Nabi SAW, dan para ulama salaf kedalam praktik kehidupan di pesantren, tercermin dalam berikut: ketaatan beribadah ritual secara maksimal, penerimaan atas kondisi materiil yang relatif serba kurang, dan kesadaran kelompok (esprit de corps) yang tinggi. Unsur kedua, pengekangan (ostracization), yang memiliki perwujudan utama dalam disiplin sosial yang ketat di pesantren.

Kedudukan yang dominan dalam pembentukan tata nilai di lingkungan pesantren di pegang oleh hukum fiqih, kemudian diikuti oleh adat kebiasaan kaum sufi. Nilai yang bertentangan dengan hukum fiqih, bagaimanapun tidak berartinya (seperti pembungaan uang), tentu tidak mendapatkan tempat di pesantren. Oleh karena itu, tidaklah tepat untuk menggukur cara penilaan di pesantren dengan apa yang terdapat di luarnya. Pengertian kebersihan, dapat di jadikan contoh dalam hal ini. Menurut fiqih, kebersihan adalah bebasnya seseorang dari tempat atau pemakaian yang mengandung najis (kotoran) yang menghalangi ke absahan

15 Ibid, hlm. 11

16 Ibid, Hlm. 13 


\section{DIROSAT}

Journal of Islamic Studies

Volume 6, No 1 Januari-Juni 2021

ISSN: 2541-1667 (print); 2541-1675 (online)

ibadahnya tentu saja konotasi ini tidaklah sejalan bahkan dalam beberapa hal bertentanggan dengan pengertian sehari-hari di masyarakat akan kebersihan, yang lebih di tekankan pada kerapian dan hilangnya noda lahiriyah. ${ }^{17}$

Maka dari itu, ada tiga elemen yang mampu membentuk pondok pesantren sebagai sebuah sub kultur, yaitu: (1) pola kepemimpinan pondok pesantren yang mandiri dan tidak terkooptasi oleh negara, 2) literatur-literatur kitab-kitab kuning sebagai rujukan umum yang selalu digunakan dari berbagai abad, dan 3) sistem nilai yang digunakan adalah bagian dari masyarakat luas. ${ }^{18}$

Adapun nilai utama di pesantren ada tiga, yaitu: pertama cara memandang kehidupan secara keseluruhan sebagai ibadah. Kedua kecintaan pada ilmu-ilmu agama. dan ketiga keikhlasan atau ketulusan bekerja untuk tujuan-tujuan bersama.

\section{Pola kepemimpinan Pondok Pesantren}

Dalam merespon perkembangan dunia pendidikan yang semakin terus berkembang, maka menuntut adanya pemimpin pesantren yang memiliki kepemimpinan yang relevan dengan kebutuhan sekarang dan masa depan serta harus mampu pula memahami kebutuhan akan integrasi pesantren ke dalam pendidikan nasional. Kepemimpinan yang dinamis di pesantren haruslah mampu mengadakan gebrakan dalam dunia pendidikan baik dalam tingkatan lokal, regional, dan nasional.

Dalam taraf lokal, Gus Dur menginginkan kepemimpinan pesantren harus mampu mengadakan proyek-proyek rintisan yang menonjolkan pada sumbangansumbangan positif pesantren bagi pendidikan nasional. Pada taraf regional, harus mampu menciptakan dukungan dan topangan bagi proyek rintisan, lebih-lebih pengayoman kepada semua pihak yang terkait delam pengembangan pendidikan. sedangkan dalam taraf nasional, kepemimpinan dalam pesantren harus mampu menyuguhkan kerangka teoritis dan filosofis bagi pembentukan pendidikan nasional yang relevan dengan kebutuhan dan Negara masa depan. ${ }^{19}$

Oleh karenanya, pemimpin pesantren dalam kepemimpinan harus memiliki pandangan jauh ke depan, tidak hanya sibuk dangan fungsi kemasyarakatan yang sempit belaka, serta jangan juga hanya disempitkan oleh pelayanan teknis pada pesantrennya sendiri saja. Yang diperlukan adalah pendayagunaan kepemimpinan yang sudah memiliki ketrampilan praktis yang sempit di bidang pengawasan, administrasi dan perencanaan itu guna tujuan yang lebih besar: yaitu bagaimana mengintegrasikan pesantren ke dalam pendidikan nasional. ${ }^{20}$

Dengan cara seperti ini kepemimpinan dinamis dipesantren dapat mencegah semakin berlarut-lartunya kemelut di pesantren, dan mengembangkan pesantren sebagai lembaga pendidikan dan kemasyarakatan yang benar-benar mampu menghadapi tantangan zaman.

\footnotetext{
17 Ibid, hlm. 26

18 Abddurrahman Wahid, Pondok Pesantren Masa Depan (Bandung :Pustaka Hidyah, 1999),

Hlm. 14.

${ }^{19}$ Ibid, Hlm. 193

${ }^{20}$ Ibid, Hlm. 194
} 


\section{DIROSAT}

Journal of Islamic Studies

Volume 6, No 1 Januari-Juni 2021

ISSN: 2541-1667 (print); 2541-1675 (online)

\section{Kurikulum Pondok Pesantren}

Menurut Gus Dur, kurikulum yang berkembang di pesantren selama ini memperlihatkan sebuah pola yang tetap. Pola tersebut dapat diringkas ke dalam pokok-pokok berikut: a) kurikulum ditujukan untuk mencetak ulama' dikemudian hari; b) struktur dasar kurikulum itu adalah pengajaran pengetahuan agama dalam segenap tingkatannya dan pemberian pendidikan dalam bentuk bimbingan kepada santri secara pribadi oleh kiai/guru; dan c) secara keseluruhan kurikulum yang ada berwatak lentur dan fleksibel, dalam artian santri berkesempatan menyusun kurikulumnya sendiri sesuai dengan kebutuhan dan kemampuannya. ${ }^{21}$

Dari sini Gus Dur berpendapat perlunya pesantren melakukan perubahan kurikulum yang lebih integrative. Santri perlu diberikan bukan hanya ilmu-ilmu yang terkait dengan ritual keseharian yang bersifat praktis-pragmatis, melainkan juga harus dibekali ilmu-ilmu yang berbau pengetahuan umum. Namun sebelumnya Gus Dur mensyaratkan perlu adanya upaya standarisasi kurikulum pesantren baik yang berskala lokal, regional maupun nasional. Menurut Gus Dur, sistem pendidikan di pesantren masih belum memiliki kesamaan dasar di luar penggunaan buku-buku wajib (kutub al-muqarranah) yang hampir bersamaan. Keragaman ini timbul sebagai akibat dari ketidaksamaan dalam sistem pendidikannya, dimana ada pesantren dengan sistem pendidikan berupa pengajian tanpa sekolah/madrasah, ada pesantren yang hanya menggunakan sistem pendidikan madrasah secara klasikal, dan sistem pesantren yang menggabungkan antara keduanya. Oleh karenanya, masih menurut Gus Dur, bahwa tidak mungkin ada penyatuan kurikulum di antara pondok pesantren salama masih adanya perbedaan-perbedaan cukup besar dalam sistem pendidikan yang dianut. ${ }^{22}$

Namun tidak semua pesantren sepakat dengan standarisasi kurikulum pesantren. Hal tersebut disadari betul oleh Gus Dur, untuk itu pembakuan yang dimaksud adalah menciptakan beberapa model kurikulum sederhana yang memungkinkan lembaga pendidikan yang menyelenggarakannya disebut sebagai pondok pesantren, terlepas dari atau tidaknya sistem madrasah di dalamnya. Kepentingan pembuatan model-model kurikulum itu adalah untuk menyediakan tingkatan ilmiah minimal bagai pengetahuan agama di pondok pesantren. Dengan tercapainya tingkatan minimal itu, pondok pesantren bersangkutan dapat memasukkan unsur-unsur pendidikan non-agama ke dalam kurikulumnya tanpa membahayakan kelestarian tugas pokok pesantren sebagai pengemban ilmu-ilmu agama yang dilandasi oleh ketiga unsur iman, Islam, dan ihsan.

Untuk itu ada beberapa ketentuan yang harus dipegangi dalam penyusunan model-model kurikulum yang dimaksud. Pertama, ketentuan untuk menghindari pengulangan ('adamut-tikrar), sepanjang tidak dimaksudkan untuk pendalaman (ta'ammuq) dan perjenjangan (tadarruj). Dengan demikian, dapat dihindarkan pemborosan waktu karena bagaimanapun tingkatan yang ingin dicapai oleh modelmodel kurikulum itu adalah tingkatan minimal dalam pengetahuan agama. Kedua, pemberian tekanan pada latihan-latihan (tamrinat), karenanya buku yang dipaia diusahakan yang seringkas mungkin dalam ilmu-ilmu alat. Ketiga, tidak dapat

${ }^{21}$ Ibid, Hlm. 145

22 Ibid, Hlm. 160 


\section{DIROSAT}

Journal of Islamic Studies

Volume 6, No 1 Januari-Juni 2021

ISSN: 2541-1667 (print); 2541-1675 (online)

dihindari adanya lompatan-lompatan yang tidak berurutan dalam penetapan bukubuku wajib (kutub al-muqarranah) selama masa pendidikan dari tahun ke tahun. Keempat, kurikulum tidak terlalu ditekankan pada buku-buku wajib tentang keutamaan akhlak (fadha'il al-a'mal), karena tujuan mencapai standart minimal tadi. $^{23}$

Dengan demikian dapat di temukan rumusan kurikulum pesantren sebagai sebuah tawaran.

a. Pemberian waktu terbanyak dilakukan pada unsur nahwu-sharaf dan fiqh karena kedua unsur ini masih memerlukan ulangan (tikrar), setidak-tidaknya untuk separo dari masa berlakunya kurikulum.

b. Mata pelajaran lain hanya diberikan selama setahun tanpa diulang pada tahuntahun berikutnya.

c. Kalau diperlukan, pada tahun-tahun terakhir dapat diberikan buku-buku utama (kutub al-muwathowwalah) seperti Shahih Bukhari atau Muslim untuk hadits atau ihya' untuk tasawuf. Dengan demikian pelajaran setahun hanya dipusatkan pada penguasaan buku utama tersebut, yang diajarkan selama beberapa kali dalam sehari hingga selesai secara keseluruhan.

Jelaslah bahwa dari kerangka komponen pendidikan agama yang sedemikian sederhana, dapat dikembangkan kurikulum yang lebih lengkap dan lebih bulat yang mampu menampung komponen pendidikan non-agama, tanpa adanya kekhawatiran penurunan tingkatan atau nilai pendidikan agama di pondok pesantren.

\section{Kesimpulan}

Berdasarkan deskripsi atas pemikiran KH. Abdurrahman Wahid mengenai pendidikan Pondok Pesantren di atas, setelah penulis lakukan analisis lebih mendalam dapat ditarik kesimpulan bahwa Pendidikan Pondok Pesantren ialah pendidikan yang didasarkan pada keyakinan religius dan bertujuan untuk membimbing atau menghantarkan peserta didik menjadi manusia yang utuh dan mandiri. Ada tiga elemen yang mampu membentuk pondok pesantren sebagai sebuah subkultur, yaitu: (1) pola kepemimpinan pondok pesantren yang mandiri dan tidak terkoptasi oleh negara, 2) literatur-literatur kitab-kitab kuning sebagai rujukan umum yang selalu digunakan dari berbagai abad, dan 3) sistem nilai yang digunakan adalah bagian dari masyarakat luas. Pola Kepemimpinan Pondok Pesantren bersifat Khirarki dan Kurikulum di pondok pesantren ditujukan untuk "mencetak" ulama di kemudian hari.

Berdasarkan kesimpulan dari penelitian ini, dapat dikemukakan beberapa saran untuk pengelola pesantren dan yang terkait dalam penelitian ini, saran yang dimaksud adalah Bagi pengelola dunia pesantren, kepemimpinan harus memiliki pandangan jauh ke depan, tidak hanya sibuk dangan fungsi kemasyarakatan yang sempit belaka, serta jangan juga hanya disempitkan oleh pelayanan teknis pada pesantrennya sendiri saja. Yang diperlukan adalah pendayagunaan kepemimpinan yang sudah memiliki ketrampilan praktis yang sempit di bidang pengawasan,

${ }^{23}$ Ibid, Hlm. 162-163 
administrasi dan perencanaan itu guna tujuan yang lebih besar: yaitu bagaimana mengintegrasikan pesantren ke dalam pendidikan nasional. tidak bisa hanya mempertahankan tradisi yang lama belaka, sebab, tradisi yang lama tak mesti relavan untuk zaman sekarang ini.

Pembaharuan kurikulum disarankan, agar kurikulum pesantren memiliki keterkaitan dengan kebutuhan lapangan kerja, baik dalam jasa maupun bidang perdagangan dan keahliannya, pesantren harus memberikan masukan bagi kalangan pendidikan, tentang keahlian apa yang sesungguhnya dibutuhkan oleh lapangan kerja yang di era globalisasi seperti sekarang ini demikian cepat dan beragam.

\section{Daftar Pustaka}

Aziz, Abd. Paradigma Pendidikan Pesantren Genggong, Probolinggo: STAI Zainul Hasan Henggong, 2012

Barton, Greg. Biografi Gus Dur, Yogyakarta: Pt. Lkis Printing, 2012

Barton, Greg. Biografi Gusdur The authorized Biography Of Abdurrahman Wahid. Yogyakarta: LKis. 2002

Faiqoh, Nyai Agen Perubahan Di Pesantren, Jakarta: Kucica, 2003

Faisol, Gus Dur Dan Pendidikan Islam, Jogjakarta: Ar-ruz Media, 2013

Haedari, Amin. Dkk, Panorama Pesantren Dalam Cakrawala Modern, Jakarta: Diva Pustaka, 2006

Hendri, Pahlawan Nasional Bukan Untuk Gus Dur, Jakarta: MAS-Media, 2010

Junaedi, Dedy. Dkk, Beyond The Symbol "Jejak Antropropologis Pemikiran dan Gerakan Gus Dur", Bandung: Rosdakarya, 2000

Khosin. Tipologi Pondok Pesantren. Jakarta: Diva Pustaka, 2006

Moleong, Lexy J. Metodologi Penelitian Kualitatif Bandung: PT Remaja Rosdakarya, 2009

Mahmud, Model-Model Pembelajaran Di Pesantren, Tangerang: Media Nusantara, 2006

Mas'ud, Dkk. Tipologi Pondok Pesantren, Jakarta: Putra Kencana, 2002

Muhajir, Noeng Metodologi Penelitian Kualitatif Yogyakarta: Rake Sarasin, 2000

Nata, Abuddin (Ed.), Sejarah Pendidikan Islam, Jakarta: PT Raja Grafindo Persada, 2010

Partanto, Pius Dkk, Kamus Ilmiah Populer, Surabaya: Arkola 2001

Syarkun, Mukhlas Ensiklopedi Abdurrahman Wahid (jilid I), Jakarta: PPPKI, Gedung Perintis, 2013

Tatang, Ilmu Pendidikan, Bandung: CV. Pustaka Setia, 2012

Thoha, Zainal Arifin Jagadnya Gus Dur, Yogyakarta: Kutub, 2010

Wahid, Abdurahman. Menggerakkan Tradisi, Yogyakarta: Pt LKsi Printing Cemerlang, 2010

1988. . Prospek Pesantren Sebagai Lembaga Pendidikan Jakarta: P3M,

Prisma Pemikiran Gusdur. Yogyakarta: LKiS. 2000.

Tuhan Tidak Perlu Dibela, Yogyakarta: Pt LKiS, 1999

Tabayyun Gus Dur, Yogyakarta: LkiS, 1998.

Zuhairi, Sejarah Pendidikan Islam, Jakarta: Pt Bumi Aksara, 2010 